\title{
The Influence Of Classical Music Therapy To Decrease Blood Pressure Of Patients With Hypertension In The Elderly
}

\author{
Christine Aden ${ }^{1 *}$, Barto Mansyah ${ }^{2}$, Berthiana. $\mathrm{T}^{3}$ \\ 1,2,3 Program Studi Sarjana Terapan, Poltekkes Kemenkes RIPalangka Raya Jalan George Obos \\ No. 30-32 Palangka Raya, Indonesia \\ * Corresponding author: \\ Email : $\underline{\text { Christine.aden@gmail.com }}$
}

\begin{abstract}
.
Hypertension is often referred to as the "silent killer", because often attack the elderly (elderly) without feeling something and unwittingly patients experience complications. One way to control blood pressure in hypertensive patients, namely the use of therapeutic interventions nonpharmacological. Reduce hypertension therapeutic uses nonpharmacological, one of classical music therapy. The purpose of Research To know the influence of classical music therapy to decrease blood pressure of patients with hypertension in the elderly. Research methods: Literature review, the database used is Google Scholar. The search is performed in the month (August-September 2021) which can be accessed full text in pdf format and scholary. The results of the identification on the third article found various categories of hypertension before the intervention, namely on the first journal the majority of hypertension in the category of mild hypertension by as much as 23 respondents (76,6\%). In the journal of the second majority of high blood pressure as much as 19 respondents (of 63.3\%). On the journal third majority of hypertension in the category of hypertension II degree as much as 9 respondents (53\%). Based on the three articles that the author found there are differences in the categorization of hypertension. Not explained in detail about the categorization is along with blood pressure values in the article that have been identified so that the author can not be mensimilarkan or leveler category of hypertension. Of the three articles that have been identified there is a decrease in blood pressure after therapy is given to classical music with a duration of 15-30 minutes and found different variations of hypertension in the third article. Based on the results of the analysis of the article consists of 3 article there is the influence of classical music therapy to decrease blood pressure of patients with hypertension in the elderly.
\end{abstract}

Keywords : Hypertension,elderly,classical music

\section{INTRODUCTION}

High blood pressure ( Hypertension ) is one of the major health problems of each country because it can trigger heart disease and stroke brain turn off. Hypertension is considered serious health problems because its presence is often not realized. The disease can continue to get worse without realizing it until it reaches a level that threatens the lives of his patients (Wade,2016).According to the World Health Organization, approximately 1 billion people worldwide suffer from hypertension which two-thirds are found in developing countries. Hypertension causes 8 million people worldwide die each year, of which nearly $25 \%$ of the population among them there are in the zone of Southeast Asia (WHO,2019). One of them is in Indonesia, according to Basic Health Research (Riskesdas 2018) prevalence of hypertension in Indonesia by $34.1 \%$. Cases of hypertension is increasing in every country and be aware of the prevalence of elderly people who suffer from hypertension in Indonesia amounted to more than 600 million people (Triyanto,2017). The elderly are the age group 60 years and above who are prone to physical health. According to the WHO, the elderly are divided into several groups: middle age is 45 - 59 years old, the elderly, namely 60-74 years, elderly parents that 75-90 years, the very old age of 90 years and over. (WHO,2018).

Hypertension can lead to complications such as stroke,coronary heart disease (CHD), kidney disorders and others that result in weakness of the function of vital organs such as the brain,kidneys,heart, and can end up on disability and even death. Hypertension is often called the silent killer is one of the risk factors most influential causes of heart disease (cardiovascular) (Delta,2016).After knowing the incidence 
and impact of hypertension, then carried out the management of hypertension which consists of therapy, pharmacological therapy and nonpharmacologic. In the pharmacological treatment for example reseprine is the most common drug used in the treatment of hypertension, but drugs that inhibit the activity sipatikoadrenergik by removing a portion of noradrenaline stored on the wall of the artery Delta (2016). In addition to pharmacological treatment, the management of hypertension with non-pharmacological ways, namely by addressing lifestyle such as settings diet, regular exercise, the use of aromatherapy and music therapy. Regular exercise and dietary adjustments generally proven to lower blood pressure, however, the use of music as a treatment nonpharmacologic still in the developmental stage (Klementinasaing,2013).

Management of music therapy as a therapeutic tool can repair, maintain, improve the state of mental, physical and emotional. For patients with hypertension music can be used as a therapy is effective for lowering blood pressure. The duration of the effective time to hear the music 15-30 minutes. Music is a fusion of the rhythm, rhythm, harmonic, and melodic, since the first of which is believed to have an influence on the treatment of sick people. Along with the development of times researchers are interested to the music and how its influence on health are also experiencing growth (Ismarina,2015).One of the music therapy is used with listening to classical music. Classical music can reduce anxiety and stress so that the body undergoes relaxation, which resulted in a decrease in blood pressure and heart rate (Klementinangsaing,2013). Classical music is a rare item for humans in the modern era such as jazz, ballads, etc. but thanks to the strains of the tune is believed to be able to provide positive effects for human life. The influence of classical music that is as entertaining effect (entertaining), and as enriching - mind effect (make the mind positive).

Because the strains of classical music can affect the heart rate, causing peace because of the music with the gentle rhythm of the listening through the ears will go directly to the brain and directly processed so as to produce a very good effect on a person's health (Jasmarizal, 2013). Stimulation of music in music therapy was able to activate the limbic system which is associated with the emotions, while the limbic system gets activated brain to be relaxed, these conditions can trigger a person's blood pressure decreased. The strains of music in music therapy can stimulate the body to produce molecules of nitic oxide (NO). The molecule is working on the tone of the blood vessels, which can reduce a person's blood pressure (Suherly, 2012). As a supporting therapy non-pharmacological, music plays an important role in improving the ability to fight diseases. This can be achieved because music helps balance emotions and gets rid of depression patients and also reduce the anxiety, or a sense of pressure is obtained, which becomes one of the causes of increasing a person's blood pressure or hypertension (Mahatidanar, 2016). Based on the problem and the description above hypertension is a disease that is most often found in the elderly and has not been many studies about the influence of classical music therapy for elderly patients with hypertension makes the writer interested in discussing a topic about the influence of classical music therapy to patients with hypertension in the elderly, then based on that of the author of lifting the title : "the Influence of Classical Music Therapy To Decrease Blood Pressure of Patients with Hypertension In the Elderly".

\section{METHODS}

From the search results articles through the databases of Google Scholar using the keywords according to the MeSH (Medical Subject Headings). Researchers found 47 articles national research from the Google Scholar corresponding keywords that have been determined. Of the 47 articles diekslusi by reason of the topic of research not in accordance with the inclusion criteria of the researchers so that the obtained 20 articles. Of the 20 articles were then dieksklusi return with the reason of the articles that did not meet the inclusion criteria the researchers that the journal is locked, the journal is not full text, journal already removed and the journal could not be accessible in Google Scholar, so that the obtained 6 of the article. 6 the article then diekslusi return with the reason for the characteristic age of the respondents is less than 60 , the method used is qualitative so that the obtained 3 articles that will be used and meet the inclusion criteria. The results of the research made in the flow diagram based on the PRISMA (Preffend Reporting Items for Systematic Reviews and Meta Analyses). 


\section{RESULTS AND DISCUSSION}

a. Analysis

Based on the three journals that identified the author, found reduction in blood pressure after therapy is given to classical music can be seen in table 6.1, 6.2, 6.3 below :

Table 1. frequency Distribution of blood pressure before and after intervention in the Elderly

Posyandu Desa Waleng Girimarto Wonogiri (MN Fatakh,2018)

Blood pressure before intervention

\begin{tabular}{r|l|c|c|c}
\hline No & Blood Pressure & Time Frequency & $\begin{array}{l}\text { Therapy } \\
\text { (minutes) }\end{array}$ & Percentage (\%) \\
\hline 1 & Normal & 0 & 30 & $0,0 \%$ \\
2 & Normal high & 0 & 30 & $0,0 \%$ \\
3 & Hiertensi light & 23 & 30 & $76,6 \%$ \\
4 & Hypertension & 5 & 30 & $6,7 \%$ \\
5 & Severe hypertension & 2 & 30 & $6,8 \%$ \\
6 & Malignant hypertension & 0 & 30 & $0,0 \%$ \\
\hline & Total & $\mathbf{3 0}$ & $\mathbf{3 0}$ & $\mathbf{1 0 0 \%}$ \\
\hline
\end{tabular}

\begin{tabular}{|c|c|c|c|c|}
\hline & Total & 30 & 30 & $100 \%$ \\
\hline \multicolumn{5}{|c|}{ Blood pressure after intervention } \\
\hline No & Blood Pressure & Time Frequency & $\begin{array}{l}\text { Therapy } \\
\text { (minutes) }\end{array}$ & Percentage (\%) \\
\hline 1 & Normal & 0 & 30 & $0,0 \%$ \\
\hline 2 & Normal high & 20 & 30 & $66,7 \%$ \\
\hline 3 & Hiertensi light & 7 & 30 & $23,3 \%$ \\
\hline 4 & Hypertension & 3 & 30 & $10 \%$ \\
\hline 5 & Severe hypertension & 0 & 30 & $0,0 \%$ \\
\hline \multirow[t]{2}{*}{6} & Malignant hypertension & 0 & 30 & $0,0 \%$ \\
\hline & Total & 30 & 30 & $100 \%$ \\
\hline
\end{tabular}

Based on the above table it is known researchers using the classification of hypertension according to $\mathrm{WHO}$ and found 6 categories of hypertension. Before the intervention there are three categories of blood pressure, namely mild hypertension, hypertension and severe hypertension. From the third category is obtained the majority of hypertension by as much as 23 respondents in the category of mild hypertension $(76,6 \%)$. After intervention there are three categories of blood pressure that is normal blood pressure is high, mild hypertension and hypertension. Of the three categories is achieved blood pressure reduction with the majority of hypertension by as much as 20 respondents in the category of normal blood pressure high $(66,7 \%)$ with duration of therapy for 30 minutes.

Table 2. Distribution of the frequency of blood pressure before and after intervention in Panti Sosial Tresna Werdha (S Syahrial,2019)

\begin{tabular}{lccc}
\hline \multicolumn{1}{c}{ Blood pressure before the act } & Time & $\begin{array}{c}\text { Frequency } \\
\text { therapy } \\
\text { (minute) }\end{array}$ & $\begin{array}{c}\text { Percentage } \\
\mathbf{( \% )}\end{array}$ \\
\hline High & 19 & 17 & $63,3 \%$ \\
\hline Low & 11 & 17 & $36,7 \%$ \\
\hline Total & $\mathbf{3 0}$ & $\mathbf{1 7}$ & $\mathbf{1 0 0 \%}$ \\
\hline Blood pressure after Action & Time & $\begin{array}{c}\text { Frequency } \\
\text { therapy } \\
\text { (minute) }\end{array}$ & $\begin{array}{c}\text { Percentage } \\
\mathbf{( \% )}\end{array}$ \\
\hline High & & 17 & $26,7 \%$ \\
\hline Low & 8 & 17 & $73,3 \%$ \\
\hline Total & 22 & $\mathbf{1 7}$ & $\mathbf{1 0 0 \%}$ \\
\hline
\end{tabular}

Based on the above table found 2 categories of blood pressure. Before the intervention there are two categories of blood pressure is high blood pressure and low blood pressure. Of the second category are obtained in the majority of hypertension as much as 19 respondents in the category of high blood pressure (of $63.3 \%$ ). After intervention showed decrease blood pressure with the majority of hypertension as much as 22 respondents in the category of low blood pressure $(73,3 \%)$ with duration of therapy for 17 minutes. 
Table 3. The Frequency distribution of blood pressure before and after intervention in the Orphanage Elderly Bina Bhakti Werdha,Indonesia (D Fitriani,2020)

\begin{tabular}{|c|c|c|c|c|c|}
\hline \multirow[t]{2}{*}{ Blood pressure } & \multicolumn{2}{|c|}{$\begin{array}{c}\text { Blood Pressure before } \\
\text { intervention }\end{array}$} & \multicolumn{2}{|c|}{$\begin{array}{l}\text { Blood Pressure } \\
\text { after } \\
\text { intervention }\end{array}$} & \multirow{2}{*}{$\begin{array}{c}\begin{array}{c}\text { Treatment } \\
\text { Time } \\
\text { (minute) }\end{array} \\
\text { m }\end{array}$} \\
\hline & n & $\%$ & $\mathbf{n}$ & $\%$ & \\
\hline Pre-Hypertension & - & - & 1 & 6 & 15 \\
\hline $\begin{array}{l}\text { Hypertension I } \\
\text { degree }\end{array}$ & 5 & 29 & 11 & 65 & 15 \\
\hline $\begin{array}{l}\text { Hypertension II } \\
\text { degree }\end{array}$ & 9 & 53 & 3 & 18 & 15 \\
\hline $\begin{array}{l}\text { Hypertension III } \\
\text { degree }\end{array}$ & 3 & 18 & 2 & 11 & 15 \\
\hline Total & 17 & 100 & 17 & $\begin{array}{c}10 \\
\mathbf{0}\end{array}$ & 15 \\
\hline
\end{tabular}

Based on the above table it is known researchers using the classification of hypertension according to JNC VIII ( Joint National Committee ) and found 4 categories of hypertension. Before the intervention there are three categories of blood pressure of hypertension I degree, hypertension II degree and hypertension III degree. From the third category is obtained the majority of hypertension as much as 9 respondents in the category of hypertension II degree (53\%). After the intervention showed a decrease in blood pressure with the majority of hypertension by 11 of respondents in the category of hypertension I degree $(65 \%)$ with duration of therapy time for 15 minutes.

\section{b. Discussion}

The identification of blood pressure before therapy is given to classical music in the elderly The results of the research, the first journal in the Elderly Posyandu Desa Waleng Girimarto Wonogiri there are characteristics of respondents based on age, gender, education and work. Before the intervention, music therapy classic authors perform a blood pressure measurement and the author categorizes the blood pressure to normal blood pressure, normal blood pressure is high, mild hypertension, hypertension, severe hypertension and malignant hypertension. The results of the measurement of the blood pressure found as many as 23 respondents had mild hypertension $(76,6 \%), 5$ of the respondents were hypertension $(6,7 \%), 2$ of the respondents severe hypertension $(6,8 \%)$. The authors write that most of the majority of hypertension because the respondents had not yet given classical music therapy and less attention to diet and exercise. The results of research journals both in Panti Sosial Tresna Werdha Lotus Was the author categorizes the blood pressure to high blood pressure and low blood pressure.

The results of blood pressure measurement before therapy is given to classical music as much as 19 respondents had high blood pressure (of 63.3\%) and 11 respondents in the category of low blood pressure $(36,7 \%)$.The results of the research journal third in the Orphanage Elderly Bina Bhakti Werdha the authors categorize the blood pressure to be pre-hypertension, hypertension degrees I, hypertension stage II, hypertension III degree. The results of blood pressure measurement before therapy is given to classical music as much as 9 respondents had hypertension II degree (53\%), 5 of the respondents hypertension I degree (29\%), 3 respondents of III degree (18\%). Of the third article of the above authors find that every writer perform blood pressure measurement before therapy is given to classical music and each author wrote a wide variety of blood pressure categories in the research.Based on the three articles that the author found there are differences in the categorization of hypertension. Not explained in detail about the categorization is along with blood pressure values in the article that have been identified so that the author can not be mensimilarkan or leveler category of hypertension.

Table 4. Menurut Organisasi Kesehatan Dunia (WHO) klasifikasi hipertensi dibagi menjadi 6 kategori:

\begin{tabular}{lcc}
\hline \multicolumn{1}{c}{ Category } & Blood Pressure (mmHg) & $\begin{array}{c}\text { Systolic Diastolic blood } \\
\text { Pressure (mmHg) }\end{array}$ \\
\hline Normal & $<130$ & $<85$ \\
\hline Normal high & $130-139$ & $85-89$ \\
\hline Mild hypertension & $140-159$ & $90-99$ \\
\hline & https://ijhp.net &
\end{tabular}




\begin{tabular}{lcc}
\hline Hypertension & $160-179$ & $100-109$ \\
\hline Severe hypertension & $>180$ & $>110$ \\
\hline Malignant hypertension & $>210$ & $>120$ \\
\hline
\end{tabular}

Table 5. According to Joint National Committee (JNC-VII) classification of hypertension is divided into 5 categories:

\begin{tabular}{lcc}
\hline \multicolumn{1}{c}{ Category } & Blood Pressure (mmHg) & $\begin{array}{c}\text { Systolic Diastolic blood } \\
\text { Pressure (mmHg) }\end{array}$ \\
\hline Normal & $<130$ & $<85$ \\
\hline Pre-Hypertension (high Normal) & $130-139$ & $85-89$ \\
\hline Hypertension I degree & $140-159$ & $90-99$ \\
\hline Hypertension II degree & $160-179$ & $100-109$ \\
\hline Hypertension III degree & $>180$ & $>110$ \\
\hline
\end{tabular}

\section{The identification of blood pressure after therapy is given to classical music in the elderly}

The results of the research, the first journal in the Elderly Posyandu Desa Waleng Girimarto Wonogiri after therapy is given to classical music with a duration of 30 minutes known to many as 20 respondents experienced a decrease in blood pressure in the category of normal blood pressure high $(66,7 \%)$, 7 respondents mild hypertension (23,3\%) and 3 respondents were hypertension (10\%). The results of research journals both in Panti Sosial Tresna Werdha Lotus Was after therapy is given to classical music with a duration of 17 minutes known to many as 22 respondents experienced a decrease in blood pressure in the category of low blood pressure $(73,3 \%)$ and 8 of the respondents in the category of high blood pressure (26,7\%).The results of the research journal third in the Orphanage Elderly Bina Bhakti Werdha after therapy is given to classical music with a duration of 15 minutes known to many as 11 respondents experienced a decrease in blood pressure in tags hypertension I degree (65\%), 3 of the respondents hypertension II degree $(18 \%), 2$ of the respondents hypertension III degree (11\%) and 1 of the respondents in the category of prehypertension $(6 \%)$.

The duration of classical music therapy is effective or optimal is still unknown. Often the duration of which is given in the therapy of classical music is for 15 to 35 minutes, but for the health problems that are more specific music therapy is given with the duration of 30 to 45 minutes. When listening to music therapy clients lay with a comfortable position, while the tempo should be a bit slower, $50-70$ beats $/ \mathrm{min}$, using the rhythm of the calm (Schou,2016). Of the third article above, the researcher found that each author has a variation of the duration of time each in its research. In the second article with a duration of 17 minutes, there are many respondents who experienced a decrease in blood pressure, known journal of the second respondent as much as 30 with a time duration of therapy is short. Fast or slow decline in blood pressure depending on the excitability of the alpha wave (When the brain is in standby or ready meditate on that's when alpha waves appear) which stimulates peptide release endorphins B that will make respondents feel calm and a decline in blood pressure significant (D Fitriani,2020). The results of the research of the article first, second and third unidirectional or it can be said that the results of the research of the third journal is interconnected related to the influence of classical music therapy to patients with hypertension of the elderly. We can see in the journals of the first, second, third variation of the duration of time in therapy of classical music. From the third journal can be concluded that the influence of classical music therapy to decrease the blood pressure of patients with hypertension in the elderly.

\section{CONCLUSION}

Based on the results of the identification is performed on the elderly about the influence of Classical Music Therapy to Decrease Blood Pressure of patients with Hypertension in the Elderly can be concluded, that: 


\section{a. Blood pressure before intervention classical music}

The results of the identification on the third article found various categories of hypertension, namely on the first journal the majority of hypertension in the category of mild hypertension by as much as 23 respondents (76,6\%). In the journal of the second majority of high blood pressure as much as 19 respondents (of $63.3 \%$ ). On the journal third majority of hypertension in the category of hypertension II degree as much as 9 respondents (53\%). Based on the three articles that the author found there are differences in the categorization of hypertension. Not explained in detail about the categorization is along with blood pressure values in the article that have been identified so that the author can not be mensimilarkan or leveler category of hypertension.

\section{b. Blood pressure after the intervention classical music}

The results of the identification on the third article found variations in the duration of therapy given that on the first journal, there are 20 respondents experienced a decrease in blood pressure in the category of normal blood pressure high $(66,7 \%)$ with duration of therapy is 30 minutes. Journal of second there are 22 respondents experienced a decrease in blood pressure to low blood pressure $(73,3 \%)$ with duration of therapy $17 \mathrm{~min}$. Journal on the third there are 11 respondents experienced a decrease in blood pressure in the category of hypertension I degree (65\%) with a duration of therapy of 15 minutes. On the duration of 17 minutes, there are a lot of respondents experienced a decrease in blood pressure.

\section{c. The influence of classical music therapy to decrease blood pressure of patients with hypertension in the elderly}

Of the three articles that have been identified are penuruunan blood pressure after therapy is given to classical music with a duration of 15-30 minutes and found different variations of hypertension in the third article.

\section{- Conflict of Interest}

In writing the Literature Review or summary of the overarching against the previous journals, the author declares there is no conflict/issues with the other party in writing.

\section{REFERENCES}

[1] Andhika Mahatidanar H, K. N., 2017. Pengaruh Musik Klasik Terhadap Penurunan Tekanan Darah Pada Lansia. Artikel Penelitian, 4(2), Pp. 265-268.

[2] Delta, M.N. 2016. Epidemiologi Penyakit Tidak Menular. Jakarta:Rineka Cipta

[3] Dewi Fitriani, R. D. P. P. C. S. P., 2020. Effect Of Classical Music On Blood Pressure In Elderly With Hypertension In Bina Bhakti Werdha Elderly Nursing Home, Indonesia. Malaysian Journal Of Medicine And Health Sciences, November, Issue 16, Pp. 142- 144.

[4] Dewi Ismarina, H. H. P. W. M., 2015.Perbandingan Perubahan Tekanan Darah Lansia Penderita Hipertensi Setelah Dilakukan Terapi Musik Klasik Dan Relaksasi Autogenik Di Wilayah Kerja Puskesmas Pembina Palembang. Jurnal Keperawatan Sriwijaya, II(2), Pp. 124-129.

[5] Fatakh, M. N., Rusyani, Y., \& Hermawati, E. (2018). Pengaruh Terapi Musik Klasik Terhadap Penurunan Tekanan Darah Pada Lansia Di Posyandu Lansia Desa Waleng Girimarto Wonogiri. Stikes Dutagama Klaten, 10(2), 1-9. DOI Https://Dx.Doi.Org/10.5737/V10i2.424

[6] Jasmarizaal, L. S. Y., 2013. Pengaruh Terapi Musik Klasik (Mozart) Terhadap Penurunantekanan Darah Sistolik Pada Lansia Dengan Hipertensi Di Wilayahkerja Puskesmas Air Dingin Kecamatan Koto Tangah Padangtahun 2011. Academia, Pp. 1-11.

[7] JBI,2020.JBI GLOBAL. [Online] Available At: Https://Jbi.Global/Sites/Default/Files/202008/Checklist_For_Quasi-Experimental_Appraisal_Tool.Pdf

[8] Koa, A. (2020). Potensi Terapi Musik Klasik Menurunkan Tekanan Darah Pada Pasien Hipertensi: Potency Classical Music Therapy Decreasing Blood Pressure To Hypertension Elderly. Media Komunikasi Kesehatan Husada, 1(1), 1-10.

[9] Masyarakat, B. K. D. P., 2019. Kementrian Kesehatan Republik Indonesia. [Online] Available At: Https://Www.Kemkes.Go.Id/Article/View/19051700002/Hipertensi-Penyakit-Paling-Banyak-DiidapMasyarakat.Html

[10] Netty Herawati, K. M. S. W. D. A. T. M., 2018. Pengaruh Terapi Musik Klasik Terhadap Penurunan Tekanan Darah Pada Lansia Dengan Hipertensi Di Kelurahan Simpang Rumbio Wilayah Kerja Puskesmas Ktk Kota 
Solok. Menara Ilmu, 12(3), Pp. 91-98.

[11] SAING, S. K. Klementinasaing, Saloma. 2010. Pengaruh Musik Klasik Terhadap Penurunan Tekanan Darah. Jurnal USU.. Repositori Institusi Universitas Sumatera Utara, Pp. 1-54.

[12] Schou, K 2016, Music Therapy For Post Operative Cardiac Patients: A Randomized Controlled Trial Evaluating Guided Relaxation With Music And Music Listening On Anxiety, Pain, And Mood. Indimedia, Department Of Communication, Aalborg University, Aalborg.

[13] Suherly, Muhammad, Dkk. (2012). Perbedaan Tekanan Darah Pada Pasien Hipertensi Sebelum Dan Sesudah Pemberian Terapi Musik Klasik Di RSUD Tugurejo Semarang

[14] Syahrial, S., 2019. Pengaruh Terapi Musik Klasik Terhadap Penurunan Tekanan Darah Pada Pasien Hipertensi Di Panti Sosial Tresna

[15] Werdha Teratai Di Palembang Tahun 2019. Sekolah Tinggi Ilmu Kesehatan Mitra Adiguna Palembang, 7(2), Pp. 475-483.

[16] Syafnidawaty, 2020. Universitas Raharja. [Online] Available At:Https://Raharja.Ac.Id/2020/11/04/Apa-ItuPopulasi-Dan-Sampel-Dalam- Penelitian/[Diakses Kamis 9 2021].

[17] Triyanto, Endang. 2014. Pelayanan Keperawatan Bagi Penderita Hipertensisecara Terpadu. Yogyakarta : Graha Ilmu.

[18] Wade Carlson. 2016. Mengatasi Hipertensi. Bandung: Nuansa Cendikia. 